\title{
A new species of Alcantarea (E. Morren ex Mez) Harms, Bromeliaceae
}

\author{
Leonardo M. Versieux ${ }^{1,2}$ and Maria das Graças Lapa Wanderley ${ }^{1}$
}

Received: 31.05.2007; accepted: 03.09.2007

ABSTRACT - (A new species of Alcantarea (E. Morren ex Mez) Harms, Bromeliaceae). Alcantarea patriae Versieux \& Wand. (Bromeliaceae, Tillandsioideae), a new species from southeastern Brazil, is described and illustrated. It grows on inselbergs within the Atlantic Forest vegetation at Jerônimo Monteiro County, Espírito Santo State. The new taxon shows some morphological similarities with $A$. odorata (Leme) J.R. Grant, having ligulate long attenuate leaves and sweet scent yellow flowers. However, A. patriae has a very characteristic inflorescence, with the primary bracts shorter than the lateral peduncles, suberect to erect flowering branches (vs. patent to pendulous in A. odorata), with more spaced flowers (20-30 vs. $8-15 \mathrm{~mm}$ ) and also a wider rosette, up to $1.6 \mathrm{~m}$ diam.

Key words: Atlantic Forest, Espírito Santo, inselberg, Tillandsioideae

RESUMO - (Uma nova espécie de Alcantarea (E. Morren ex Mez) Harms, Bromeliaceae). Alcantarea patriae Versieux \& Wand. (Bromeliaceae, Tillandsioideae) uma nova espécie do Sudeste do Brasil, é descrita e ilustrada. Cresce em inselbergs em meio à vegetação de Mata Atlântica no município de Jerônimo Monteiro, estado do Espírito Santo. O novo táxon mostra algumas similaridades morfológicas com $A$. odorata (Leme) J.R. Grant, apresentando folhas liguladas longo-atenuadas e flores amarelas com odor adocicado. No entanto, A. patriae apresenta uma inflorescência muito característica, com brácteas primárias menores do que os pedúnculos laterais, ramos floríferos de suberetos a eretos (vs. de patentes a pêndulos), com flores mais espaçadas (20-30 vs. 8-15 mm) e uma roseta maior, de até 1,6 m de diâmetro.

Palavras-chave: Espírito Santo, inselberg, Mata Atlântica, Tillandsioideae

\section{Introduction}

The genus Alcantarea (E. Morren ex Mez) Harms, which is named after a former emperor of Brazil (i.e., Dom Pedro de Alcântara), is endemic of Brazil, occurring on inselbergs in the Atlantic Forest of Bahia, Minas Gerais, Espírito Santo, Rio de Janeiro, and São Paulo States, and also on rock outcrops of Campo Rupestre of the Espinhaço mountain chain (Baker 1889, Versieux \& Wanderley 2007). Recent studies on the genetic structure of Alcantarea species have revealed that there is a high degree of population isolation for inselberg Alcantarea species what should favor speciation (Barbará et al. 2007).

Alcantarea includes near 22 species, frequently cultivated due to the beauty of their foliage and inflorescences. Most species are inadequately represented in the scientific collections, due to difficulties in accessing their habitats on rocky cliffs, and also by their large size. As a consequence, some species remain poorly understood taxonomically. The new species proposed here is part of the results of the systematic revision conducted by the authors.

\section{Results and Discussion}

Alcantarea patriae Versieux \& Wand., sp. nov. TYPE: BRAZIL. EsPíRITo S ANTo: Jerônimo Monteiro, Vila Cruzeiro, inselberg, 2047'46.6”'S, 41'21'55.1”W, 136 m.s.m., 18-I-2007 [fl.], L.M. Versieux 365, A.M. Calvente \& T. Trindade (holotype SP; isotypes BHCB, HUEFS, MBM, MBML, R, SPF).

Figures 1-2

A Alcantarea odorata (Leme) J.R. Grant similis sed habita majore, ramis inflorescentiarum majoribus, (20-50 cm vs. ad usque $16 \mathrm{~cm})$, suberectis differt.

Saxicolous, caulescent, 2-3.7 $\mathrm{m}$ high, propagating by basal shoots. Rosette infundibuliform, storing a large amount of water, ca. $1.5 \times 1.6 \mathrm{~m}$. Leaves numerous,

1. Instituto de Botânica, Caixa Postal 3005, 01061-970 São Paulo, SP, Brasil

2. Author for correspondence: lversieux@yahoo.com.br 


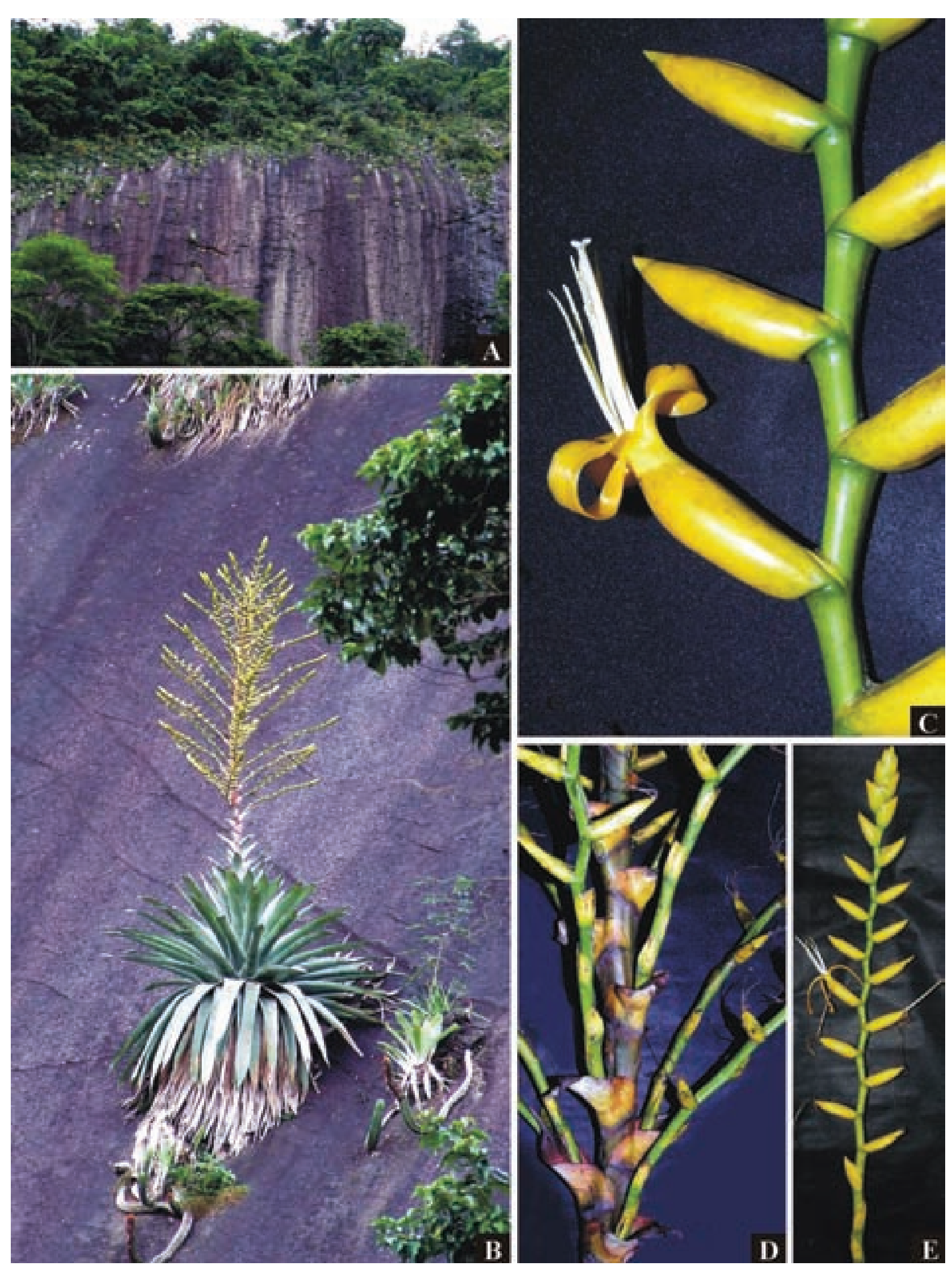

Figure 1. Alcantarea patriae Versieux \& Wand. A. Habitat, B. Blooming individual, C. Detail of the flower at anthesis, D. Detail of the inflorescence, E. Flowering branch (C-E from the holotype. Photos: L.M. Versieux). 


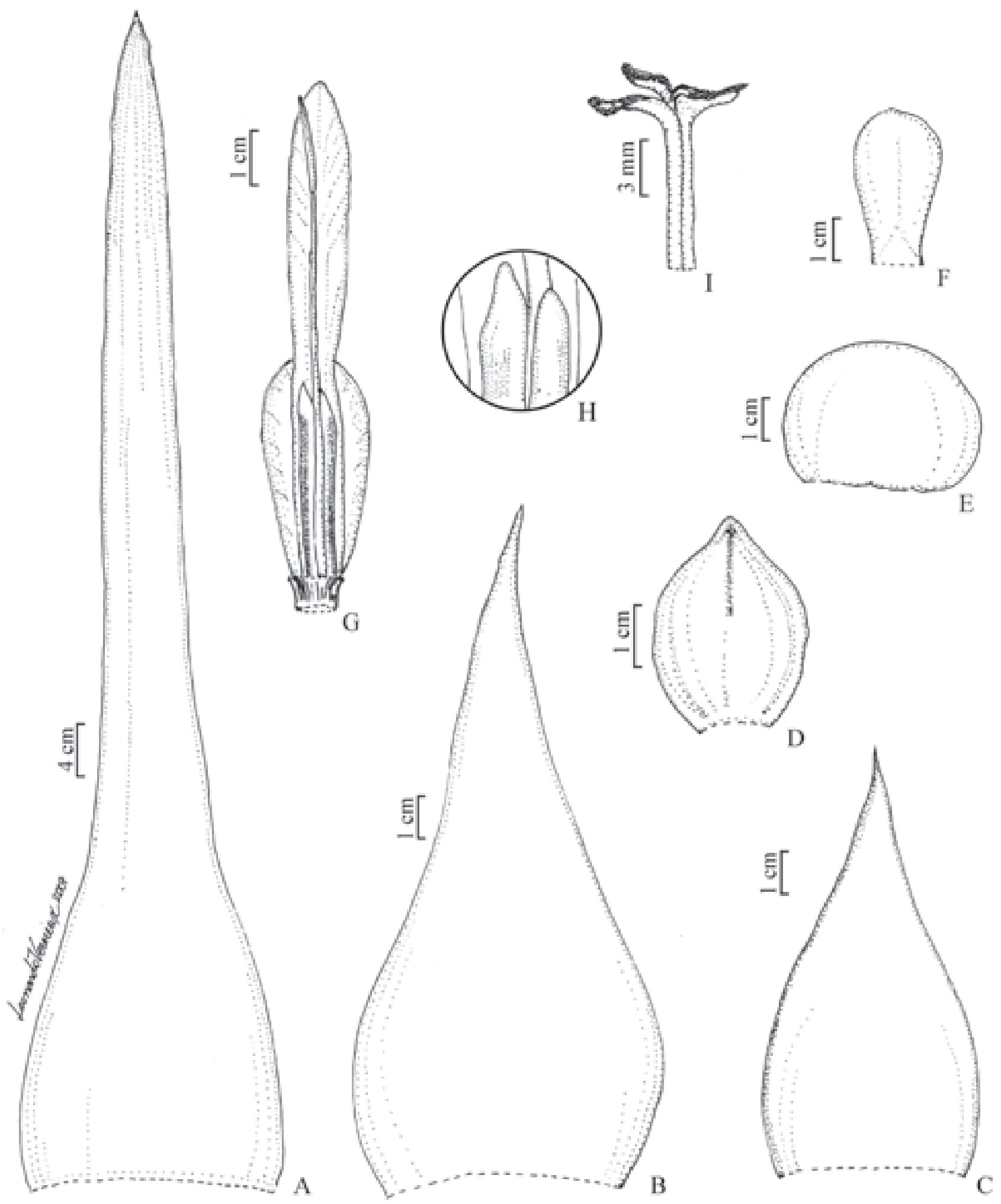

Figure 2. Alcantarea patriae Versieux \& Wand. A. Leaf, B. Scape bract, C. Primary bract, D. Sterile bract, E. Floral bract, F. Sepal, G. Petal with antipetalous stamen, sepal and part of hypanthium at the base, H. Detail of the petal appendages, I. Stigma (from the holotype). 
suberect, nearly straight; sheaths elliptic to widely ovate, 30-43 $\times 15-21 \mathrm{~cm}$, pale brown with brown spots and pale brown inclined lines abaxially, white along the insertion becoming pale brown adaxially when fresh, dark brown becoming pale brown abaxially, concolor pale brown adaxially when dry, densely brown lepidote on both faces, coriaceous, margins membranaceous, inconspicuously wine-red spotted when fresh, strongly involute when dry; blades ligulate to ligulate-lanceolate, $(0.9-) 1-1.2 \mathrm{~m} \times 9-10 \mathrm{~cm}$, concolor green, with transversal white wax bands on both faces, densely brown lepidote abaxially, glabrescent adaxially, plane to slightly canaliculate, suberect, coriaceous, distinctly nerved with some prominent veins, margins green, weakly revolute when dry; blade apex acute, green, twisted, rigid, discretely apiculate for ca. $5 \mathrm{~mm}$. Scape erect, straight, stout, $80-130 \times 2.6-4 \mathrm{~cm}$, terete to slightly sulcate, brownish green to purplish green, glabrous, distinctly nerved, internodes 3.5-6.5 cm; scape bracts: the proximal ones, subfoliaceous, green, the middle and distal ones, ovate, apex acute, apiculus twisted, 15-35 × 4-6 cm, red at base passing to pale green, covered by white wax and densely brown lepidote abaxially, wine-red spotted and sparsely lepidote adaxially, imbricate up to $1 / 3$ of the length, curved and spreading toward the apex, distinctly nerved, coriaceous, margins revolute when dry. Inflorescence compound, heterothetic double raceme, ellipsoidal, $45-100 \times 25-50 \mathrm{~cm}$, main axis with $2-5 \times 1-3 \mathrm{~cm}$ internodes; primary bract ovate, apex acute, discretely apiculate, twisted, 4-13.5 $\times$ 2.8-5.5 cm, yellowish green to yellow along the base passing to waxy white abaxially, wine-red adaxially, densely brown lepidote on both faces, involute, curved, shorter than the lateral peduncles, distinctly nerved, coriaceous; inflorescence branches 20-27, 11-26(-32)flowered, suberect to erect; lateral peduncles terete, (4-)12-22 × 0.7-0.9 cm, green, glabrous, finely nerved; sterile bracts 2-4(-6), elliptic to oblong, apex acuminate, discretely apiculate, $3-3.8 \times 1.5-2 \mathrm{~cm}$, yellow, apiculus wine-red, glabrescent abaxially, densely brown lepidote adaxially, adpressed to the lateral peduncle, remote or nearly so, finely nerved, carinate near the apex, coriaceous, margins membranaceous; rachis weakly geniculate to straight, nearly quadrangular in cross section, 25-50 cm, green, glabrous, internodes (20-)30 $\times 7-8 \mathrm{~mm}$; floral bract suborbicular, apex obtuse, 3.5$4 \times 4.5-5.3 \mathrm{~cm}$, yellow, glabrous abaxially, brown lepidote adaxially, involving the calyx, smooth and carnose in the central portion, nerved along the laterals and margins, ecarinate but weakly thickened in upper $5 \mathrm{~mm}$ below the apiculus, margins membranaceous, yellowish hyaline in the fresh material. Flowers with a weak sweet scent, distichous, patent to suberect at anthesis; pedicels nearly circular, $4 \times 6 \mathrm{~mm}$, green, sulcate; sepals obovate, apex obtuse, symmetric or nearly so, 3.2-3.7 × 2.3-2.7 cm, exceeding the floral bracts in 10-15 $\mathrm{mm}$, yellowish green on base, completely yellow toward the apex, glabrescent abaxially, brown lepidote adaxially, carnose, ecarinate, margins membranaceous and yellowish hyaline in the dry material; petals ligulate, constricted around the apex of the sepals, apex rounded, 85-90 $\times$ 9-10 mm, yellow, inconspicuously white spotted, turned backward and weakly spiraled at anthesis; petal appendages 2 , ligulate, ca. $34 \times 2 \mathrm{~mm}$, longitudinally adnate to the petal for $29 \mathrm{~mm}$, carnose and protuberant, apex acute, asymmetrical; stamens not spreading; filament terete, weakly complanate in the 1/2-inferior portion, 70-74 $\times 1.7 \mathrm{~mm}$, white; anther linear, ca. $16-18 \times 1.4 \mathrm{~mm}$, yellow, dorsifixed near the base; style trigonousrounded in cross section, ca. $85 \times 2 \mathrm{~mm}$, white; stigma lobes convolute-patent, $2.5-3 \mathrm{~mm}$, white; ovary weakly hexagonal in cross section, with inconspicuous ribs, ca. $15 \times 3-4 \mathrm{~mm}$, green, hypanthium ca. $6 \mathrm{~mm}$; ovules numerous, ca. $3 \mathrm{~mm}$. Capsule and seeds unknown.

Additional material examined: BRAZIL. Espírito SANTO: Jerônimo Monteiro, Vila Cruzeiro, cultivated along the road BR-482, 2048'04.8'S, 41'22'04.1'W, 131 m.s.m., 18-I-2007 [fl.], L.M. Versieux 364, A.M. Calvente \& T. Trindade (SP).

Alcantarea patriae stands out among other species of the genus due to its great dimensions, particularly those of the leaf sheath, blade, rosette and the ample inflorescence. This new taxon resembles A. odorata that also has sweet scent flowers, but it can be separated from the latter by its shorter primary bracts, by the larger number and more spaced flowers, and by the straight to weakly geniculate rachis. Furthermore the flowering branches in A. patriae are usually longer, and suberect to erect (vs. patent to pendulous). The white wax cross bands along the blades or on the abaxial face of the scape bracts, and the rachis, which is almost straight or diverging up to $5^{\circ}$ for each side (Figure 2C, E), are also very conspicuous characters that are useful to distinguish $A$. patriae.

Geographical distribution and conservation: Alcantarea patriae is helyophyte and grows over rocks between 120-400 m.s.m. at Jerônimo Monteiro 
County, Espírito Santo, Brazil. Individuals grow isolated or in dense groups frequently associated to Coleocephalocereus pluricostatus Buining \& Brederoo (Cactaceae). Based on the IUCN criteria (IUCN, 2001), Alcantarea patriae can be considered Near Threatened (NT) due to its restricted occurrence area that is not within any protected area. Although the populations are usually large, with hundreds of individuals that are on inaccessible steep slopes, A. patriae is locally exploited for the ornamental trade. Also, granite mining threatens its substrate.

Phenology: Blooming in January

Etymology: Alcantarea patriae (i.e., belonging to the native land) was named after the bright colors observed in the inflorescence branches. The green of the lateral peduncles, and rachis, together with the yellow bracts, sepals and petals remind the colors of the Brazilian flag.

\section{Acknowledgements}

This work is part of the $\mathrm{PhD}$ project of the first author, undertaken at the Botany Department,
Universidade de São Paulo. We thank the two anonymous reviewers for their comments on the manuscript; we also thank Araci and Marcionílio Azarias, for allowing plant collection in their property. Financial support was provided by FAPESP to L.M. Versieux and by CNPq to M.G.L. Wanderley.

\section{Literature cited}

Baker, J. G. 1889. Handbook of the Bromeliaceae. George Bell \& Sons, London.

Barbará, T., Martinelli, G., Fay, M.F., Mayo, S.J. \& Lexer, C. 2007. Population differentiation and species cohesion in two closely related plants adapted to neotropical high-altitude 'inselbergs', Alcantarea imperialis and Alcantarea geniculata (Bromeliaceae). Molecular Ecology 16: 1981-1992.

IUCN. 2001. IUCN red list categories and criteria: version 3.1. IUCN Species Survival Commission. IUCN, Gland, Switzerland and Cambridge, U.K.

Versieux, L.M. \& Wanderley, M.G.L. 2007. Two new species of Alcantarea (Bromeliaceae, Tillandsioideae) from Brazil. Brittonia 59: 57-64. 